\title{
Teacher's Response on the Teaching Pyramid Model-Curriculum 2013 Implementation in Kindergarten, Bandung-Indonesia
}

\author{
Yeni Rachmawati ${ }^{\mathrm{a}}$, Aan Listiana ${ }^{\mathrm{b}}$ \\ a Universitas Pendidikan Indonesia \& National Dong Hwa University, Taiwan \\ ${ }^{\mathrm{b}}$ Universitas Pendidikan Indonesia, Indonesia
}

Corresponding e-mail: yeni_rachmawati@upi.edu

\begin{abstract}
This paper would figure out the teacher's response on “Teaching Pyramid Model-Curriculum 2013” program implementation, that located in a Kindergarten, in Bandung-Indonesia. This research was using a descriptive-analytic approach as a method. Data were obtained through interviews and questionnaires that addressed to the teachers and principal. The results showed that the teacher and principals have a good response for the "Teaching Pyramid ModelCurriculum 2013" program implementation. Teachers and principals argued that some good behaviours had developed and become a new habit among the children. Some student showed more orderly, polite, neat, clean, and care. Teachers also explained that using posters and media can help a student more understand and easier to follow the rules. In general, character building on TPM-Kurtilas in a concrete way, integrated and systematic approach could facilitate children to understand and perform a good behaviour.
\end{abstract}

Keywords: Teaching Pyramid Model-Curriculum 2013, kindergarten, character building

\section{INTRODUCTION}

Character building is one of prime goal that would be reach in national education in Indonesia. This issue has been stated on the national education's goal that express in Law No. 2/1989, as follows;

"educating national life, developing a true Indonesians human being, the man who is faithful and devoted to Almighty God, then has noble character, knowledge and skills. The man who has spiritual and physical health, steady and independent personality, also has social and national responsibility".

To implement that national education goal education system needs to create learning process systematically and planned greatly (UUSPN 2003 Chapter 1 article 1 paragraph 1 and 2)

Unfortunately, in general, kindergarten teachers face challenging to teach character for the children. Some teachers feel a lack of experience to teach moral, value, religions or character in the school. Then, they teach morality or character more academically (Rachmawati, 2005). The experts said that in Indonesia, the subject of Pancasila morality and civics is more academic and theoretical than applicative (Wardhani, 2010). Similarly, in kindergarten, Teachers more focus on academic teaching. This evident from the observation of some previous researchers that teachers only prepare a learning program that focuses on academic skills like reading, writing, and arithmetic (Mumun 2009; Fuadah, 2013; Muhartini, 2013; Giyatni 2013; Arie \& Rakhmawati, 2014). Furthermore, the focus of instruction in kindergarten in general is still domination by cognitive aspects, so the character education is remains low (Olim, A. 2010; Humaida, 2013; Ratnasari, 2015)Related to this issue, Chou, Yang and Huang, (2014) point out that character building should begin in young child. In Addition, Ferdiawan \& Son (2013) emphasized that young child period is the strategic age to develop children's personality. 
TPM-Kurtis's or Teaching Pyramid ModelCurriculum 2013 (Listiana \& Rachmawati, 2016) is one of the character building models that implement in the school to solve teacher difficulties. This TPMKurtilas is adopted Teaching Pyramid Model on national curriculum 2013. The Teaching Pyramid Model is a character building program that created by Lise Fox (2003) in USA. This following would figure out the TPM-Kurtilas construction that is used for this research:

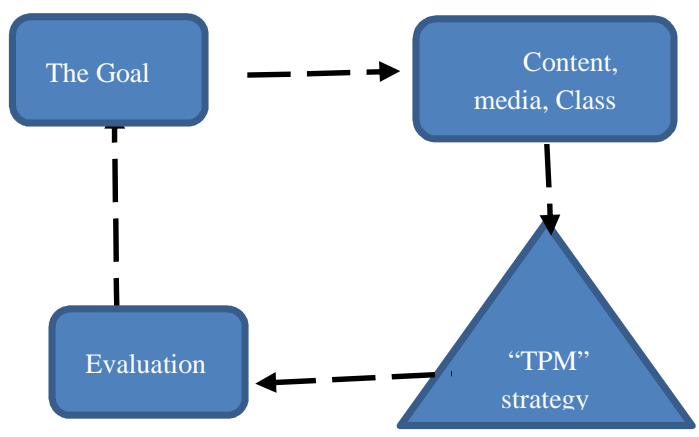

Figure.1. Model TPM -Kurtilas

(Listiana \& Rachmawati,2016)

TPM-Kurtilas is an adaptation Teaching Pyramid Model with National Curriculum 2013, which has the goal to build children character. In this model, statement of learning goal, target and contents it takes from National curriculum 2013 statement. Furthermore, preparing media and class setting are arranged to base on situation and local culture. While teaching strategy and the structured, it borrowed from Teaching Pyramid Model (Listiana \& Rachmawati, 2016). The TPM strategy and Structure had four stages of its implementation; the first one builds positive relationship between teacher and students; then, environment setting concussively; teaching activity; and the last intervention for students who need it (Fox et al, 2003)

Some previous research, discussing Teaching Pyramid Model related to teaching activity at various levels, trainings, and comparing models. The TPM research connected with teaching activity arranged by Fox et al. (2003) that elaborated TPM to support social competency and prevent the "challenging behavior" on young children. Furthermore, Fox \& Lentini (2006) studied TPM in teaching children social and emotional skills. Moreover, Hemmeter et al. (2006) trying to connect TPM with another variable. He found that TPM not only builds children social-emotional foundation, but also can help children build school readiness. In addition, another topic is TPM related to training teachers and professional workshop that doing by Fox et al. (2009) and Hemmeter et al. (2011). Moreover, Fox et al (2010) had compared the TPM with "Respond to Intervention (RtL) model." And the last, Branson \& Demchak (2010) doing research to implement TPM in toddler.

While, this article is a part of research series on TPM-Kurtilas that held in Bandung-West Java for three years' research. Some topic regarding the TPM -Kurtilas are formulated the TPM Model (Listiana\& Rachmawati, 2016), developing social-spiritual skill instrument, the effectiveness TPM-Kurtilas in school, The effect of TPM Kurtilas on changing behavior. This research is talking about the teacher opinion on TPM Kurtilas implementation in Kindergarten. The TPM-Kurtilas models need critique, comment and evaluation from stake holder and experts because the program is still new. This paper is trying to express teachers and principal respond related to TPM-Kurtilas implementation process in school.

\section{THE METHOD}

The method used for this study was descriptive approach. Data were obtained by interviews and questioners, which addressed to the teacher and principal as the implementer of the program. This research conducted in a Kindergarten, Municipality of Bandung. The implementation process takes place every day with 30 minutes in each of learning's opening (circle time). Learning materials provided related to the social and spiritual attitudes. Social attitudes include healthy behavior, curiosity, creative, aesthetic, confident, discipline, selfreliance, caring, cooperation, adaptive, honest, humble, and polite. While the spiritual attitude includes the acceptance of the teaching espoused. The program was implemented for about five months from February-June 2016.

\section{RESULT AND DISCUSSION}

\subsection{Children Positive Character}

The teacher and school principal said that after the implementation of TPM Kurtilas for about four months, the children are accustomed to do good habits such as: neat, clean, polite, sharing, caring, knowing the rules (Mrs. Esa and Mrs. Tiara 
(pseudonym, 29 June 2016). Teacher's perceived that these behaviours can be seen through the attitude of children who regularly do it. As revealed by Mrs. Esa opinion as below:

"When the children came up into the class, some of them are tidy the clothes up, comb the hair, even some of them used to wash hand; The children become calmer when eating and praying, accustomed to say hello while entering the classroom; getting more easily to be reminded about some rules, willing to put toys; saying sorry and forgiving easily".

A well-structured instruction as found in TPMKurtilas on teaching values have helped children better prepared and understand the good values that are expected embedded on them. Teaching values have been integrated manner starting with building a positive impression on the teachers and its environment, creating a sense of comfort on children, helping the process of good character establishment as expressed by Butterfield, et.al. (2013) which found that positive relationship makes the children become more brave in communication and regulating their behavior. As Lickona (1991) emphasized the importance of three components of good character namely moral feeling, moral knowing, and moral action. Reinforced by JavaPhilosophy pioneered by Ki Hajar Dewantara about tringa: ngerti-ngrasa-nglakoni or in other words mean understanding, feeling, and performing (Wardani, 2010). TPM-Kurtilas help children build positive character. With this character education that applied in systematic and sustainable way, a child would be as emotionally intelligent (Wardani, 2010).

\subsection{The Importance of Poster as a Media}

The existence of Media in teaching moral and character values not only can improve the quality of teaching and learning process but also ease the children in learning. The media as a tool can make the learning process runs effectively, understandable, concrete more in explaining an abstract image so as to reduce the occurrence of verbalism (Nurseto, 2012).

As it also happened in the Implementation of TPM-Kurtilas at school. The use of posters are helpful especially when teacher and also children implement the rules and regultions at school. The posters image the rule in the concrete way thus the children understand the rules and regulation easily. So the teacher got easy to explain the rules and build positive behavior. By poster medium, the teacher and school principal say that children become more orderly and organized. As similarly felt by Mrs. Tiara and Mrs.Esa in the field:

"Children are easier to get reminded on the rules. As when eating time, there were child whose seized/noise, the teacher or even other student just only pointed out to the eating regulations poster to remind him (Mrs.Esa (pseudonym) Wednesday, 29 June 2016)".

Naturally, poster as a graphic medium used to attract attention, clarify the grain ideas, and illustrate the facts so that it attracts people to always get remember on it (Susilana and Riyana, 2009). The advantage of poster usage as a graphic medium is also facilitating and accelerating the student's understanding on the message given (Susilana and Riyana, 2009).

\subsection{The Selection of Appropriate Materials and Media}

Realizing that children still think concretely, need a lot of repetition to understand something, the selection of appropriate materials to become a learning media is strickly done by the teachers. It is related to the teachers' concern about long lasting poster usage and other supported media that continously in use. It is stated by Mrs. Tiara and Mrs. Esa in the following quote:

“... Some media needs to be improved, such as poster boards that can be rubbed (brushing teeth procedures faded due to water exposure), brightless and less-attractive colors for children, as well as necklace name tag that disturb children's activities and they rejected directly (Mrs.Tiara (pseudonym), 29 June 2016)".

It should be noted that there are a number of criteria that must be considered in choosing the appropriate learning media including the ease of access, comliance cost, precision technology, preferred interactivity media, organization support, and novelty (Susilana and Riyana, 2012).

\subsection{It takes Time}

Character education requires considerable time to build an understanding and behavioral practice as expected. Such behavior needs to do repetitively, 
consistent, and continously. Thus, the behavior becomes an awakened habit.

One of the teachers input with regard to the Implementation of TPM-Kurtilas is that materials tested are too quickly changed and different daily. It feels like in a hurry, too quick that result in less children understanding/comprehension. (Mrs. Tiara's Questionaire, 29 June 2016).

"I recommend that every materials given have a range of time, not in a marathon, and not change the teaching focus everyday".

\subsection{The important role a Teacher as a Model}

On the Javanese philosophies, teacher is a persona that "digugu and ditiru" (be obeyed and imitated). Teacher is a model for students (Wardani, 2010). Therefore, on TPM-Kurtilas implementation, the teachers play an important role. As stated Mrs Tiara as follows:

Mrs Tiara (pseudonym) said; "the strategy that used in this program has been good, however, all implementation is depends on the teacher as a role model"(questionnaire on June $29^{\text {th }} 2016$ )

The role of teachers is not only teaching academic but also educating characters, morals and culture for their students. Relating to that issue $\mathrm{Ki}$ Hajar Dewantara emphasized that with the Javanese term "Ing ngarso sung tulodo, Ing madyo Mangun Karso, tut wuri Handayani", means that the teachers needed to become a role model, a motivator and a supporter for the children. In Indonesian society, people still expected teachers to be a model and perform a behaviour that reflected moral values. In the research, Davidson et al (2008) describe the teacher figure that students expected. He asked the students in the secondary school in the USA with a question: "how do you know that the teachers care about you? Then students identified two patterns behaviour that is crucial to figure out the teacher characteristic. They said that the teacher would teach well, means teacher would make class interesting and commitment to work. In addition, the teacher would show respect and fair. It means the teacher not interrupt, disciple, deny, ignore or shout at students. In general, the student expected teachers are someone who performed individual's capabilities, and have good character and morals integrated. According to Lickona (1991) the school institution expected to educate characters for children, particularly take across to the teaching that could develop respect and responsibility. In the book of Teacher and Lecturer Law No.14 year 2005 stated that "the teacher as professional educators have the primary task to educate, teach, guide, direct, train, assess and evaluate students in formal education on the level of early childhood education, basic education and secondary education".

\section{CONCLUSIONS}

TPM-Kurtilas implementation in kindergarten reached a good impression from teacher and principal. TPM-Kurtilas could help teachers to teach values for the children. For the children, itself, the systematic procedure on TPM-Kurtilas made children easier to understand the role. To sum up, base on the unique procedure of TPM-Kurtilas helped teacher to make simple and concrete the abstract thing from the values.

\section{ACKNOWLEDGEMENTS}

We would like to express our gratitude towards our Government RISTEKDIKTI for sponsorship and financial support on this research. Our thanks and appreciation also go to our students and colleagues for their kind cooperation and encouragement which help us to completion this project.

\section{REFERENCES}

Arie \& Rakhmawati, (2014). Upaya meningkatkan kecerdasan interpersonal melalui metode Cooperative play pada kelompok B di Daqu School International: Jurnal Penelitian PAUDIA

Book of Law No. 2/1989 Concerning National Education Goal

Branson, D., \& Demchak, M. (2010). Toddler Teachers' Use of teaching Pyramid practices. Early Childhood Special Educatin, 30(4), 196208

Butterfield, P.M., Martin, C.A., Prairie, A.P. (2003). Emotional Connections: How Relationships Guide Early Learning. Washington, D.C.: Zero To Three Press.

Chou, Mei-Ju, yang, Chen-Hsin, Huang, \& PinChen. (2014). Keindahan Pendidikan karakter di Prasekolah Anak. Taiwan: Universitas Shoufu Taiwan. 
Davidson, M., Lickona, T., \& Khmelkov, V. (2008). Smart \& good schools: A new paradigm for high school character education. Handbook of moral and character education, 370-390.

Dewantara, K.H. (1961). Bagian Pertama: Pendidikan. Jogjakarta: Madjelis Luhur Persatuan Taman Siswa

Ferdiawan, E. \& W.P. Putra. (2013). ESQ Education for Children: Character Building Based on Phylosophy of Javaness in Indonesia. Procedia, social and Behavioral Sciences, 106. 1096-1102

Fox, L., Dunlap, G., Hemmeter, M. L., Joseph, G. E., \& Strain, P. S. (2003). The Teaching Pyramid: A Model for Supporting Social Competence and Preventing Challenging Behavior in Young Children. Young Children, 58(4), 48-52.

Fox, L., \& Lentini, R. H. (2006). " You Got It!" Teaching Social and Emotional Skills. YC Young Children, 61(6), 36.

Fox, L., \& Hemmeter, M. L. (2009).A program-wide model for supporting social emotional development and addressing challenging behavior in early childhood settings. In W. Sailor, G. Dunlap, G. Sugai, \& R. Horner (Eds.), Handbook of positive behavior support (pp. 177-202.). New York, NY: Springer.

Fox, L., Carta, J., Strain, P. S., Dunlap, G., \& Hemmeter, M. L. (2010). Response to intervention and the pyramid model. Infants \& Young Children,23(1), 3-13.

Fuadah, H.L. (2013). Mengembangkan Kecerdasan Spiritual Anak Usia Dini melalui Pembelajaran dengan Metode Cerita Islami. (Skripsi). Fakultas Ilmu Pendidikan, Universitas Pendidikan Indonesia, Bandung.

Giyatni, (2013). Mengembangkan kecerdasan interpersonal melalui metode bermain peran pada kelompok B melalui metode Brmain Peran TK Al Irsyad. Jurnal Publikasi: Surakarta Universitas Muhammadiyah

Hemmeter, M. L., Ostrosky, M., \& Fox, L. (2006). Social and emotional foundations for early learning: A conceptual model for intervention. School Psychology Review, 35(4), 583.

Hemmeter, Mary Louise, et al. (2011). "Professional development related to the teaching pyramid model for addressing the social emotional development and challenging behavior of young children." International Society on Early Intervention Conference, New York
Humaida, C. (2013). Pendidikan karakter tingkat TK di Kabupaten Ponorogo tahun ajaran 2012/2013.Ponorogo : Universitas Muhammadiyah Ponorogo.

Lickona, T. (1991). Educating For Character. Bantam Books

Listiana, A., Rachmawati, Y., (2016). Pengembangan Model TPM-Kurtilas : Adaptasi Teaching Pyramid Model dalam Kurikulum 2013 Guna Pengembangan Karakter Anak Usia Dini. Bandung: PGPAUD UPI

Maryadi, B., Listiana, A. (2016). Penerapan TPMKurtilas terhadap perubahan perilaku anak.Bandung: PGPAUD UPI

Mumun, S. (2009). Pengembangan kecerdasan interpersonal anak. (Skripsi). Sekolah Tinggi Agama Islam Negeri, Pekalongan

Nurseto, T. (2012). Membuat media pembelajaran yang menarik. Jurnal Ekonomi \& Pendidikan, 8(1).

Olim, A.(2010). Mencari metode pendidikan karakter untuk PAUD : Belajar berbasis layanan (service learning). Proceedings of the 4th international conference on teacher education: join conference UPI \& UPSI

Rachmawati, Y. (2010). The Role of Music in Character building. The International Journal of Learning. 17 (9).

Ratnasari, D. (2015). Korelasi hasil penerapan pendidikan karakter dan standar tingkat pencapaian perkembangan anak dikelompok bermain batik sidoarjo.Journal Plus Unesa, Vol. 4 No.1

Susilana, R., Si, M., \& Riyana, C. (2009). Media Pembelajaran: Hakikat, Pengembangan, Pemanfaatan, dan Penilaian. CV. Wacana Prima.

UUSPN No. 20 Year 2003, on National Education System

Wardani, K. (2010). Peran Guru Dalam Pendidikan Karakter Menurut Konsep Pendidikan Ki Hadjar Dewantara. In Proceeding of The 4th International Conference on Teacher Education; Join Conference UPI \&UPSI (pp. 8-10). 